\title{
Economic analysis of using sheep to control leafy spurge
}

\author{
DEAN A. BANGSUND, DAN J. NUDELL, RANDALL S. SELL, AND F. LARRY LEISTRITZ
}

Authors are research scientist, Department of Agribusiness and Applied Economics, North Dakota State University, Fargo, N.D., 58105, research specialist, Hettinger Research Extension Center, Hettinger, N.D., 58639, and research scientist and professor, respectively, Department of Agribusiness and Applied Economics, North Dakota State University, Fargo, N.D.

\begin{abstract}
Leafy spurge (Euphorbia esula L.), a widely established exotic, noxious, perennial weed, is a major threat to rangeland and wildland in the Upper Great Plains. A deterministic, bioeconomic model, incorporating relationships between sheep grazing and leafy spurge control, grass recovery, and forage consumption by cattle, and expected costs and returns from sheep enterprises was developed to evaluate the economic viability of using sheep to control leafy spurge. Various scenarios were developed depicting likely situations facing cattle ranches adding a sheep enterprise for leafy spurge control. Two levels of flock profitability, one based on a level of proficiency achieved by established sheep ranches and one substantially lower than typically achieved in the sheep industry, were combined with debt and no-debt to represent best- and worst-case scenarios, respectively. In the bestcase situations, using sheep to control leafy spurge was economical in all of the scenarios examined. In the worst-case situations, the economics of using sheep to control leafy spurge were mixed across the scenarios examined. Leafy spurge control with poor flock proficiency, high fence expense, and unproductive rangeland generally was not economical. Situations with low fencing costs, moderately productive rangeland, and poor flock proficiency resulted in less economic loss than no treatment. Actual returns from leafy spurge control for most ranchers will likely fall between the extremes examined.
\end{abstract}

Key Words: Euphorbia esula L., grazing, economics

Leafy spurge (Euphorbia esula L.), first introduced in North America in the 19th century, was found in North Dakota in 1909, and was considered a threat to rangeland in the Upper Great Plains as early as 1933 (Hanson and Rudd 1933). The weed currently infests large amounts of untilled land in the Plains and Mountain states and creates serious economic losses for land owners and ranchers (Leitch et al. 1996). The nature of leafy spurge and the detrimental effects of the weed on untilled land have been documented (Watson 1985, Lajeunesse et al. 1995, USDA 1995).

Current control technologies are ineffective in eradicating

Funding was provided by the Agricultural Research Service through the Cooperative State Research Service of the U.S. Department of Agriculture and the North Dakota Agricultural Experiment Station.

The authors thank Drs. K. Sedivec and D. Kirby, Department of Animal and Range Sciences, and Dr. R. Lym, Department of Plant Sciences, North Dakota State University, Fargo, N.D. for development of model components used in the study.

Manuscript accepted 1 Oct. 2000.

\section{Resumen}

"Leafy spruge" (Euphorbia esula L.) Es una maleza exótica, perenne y nociva que esta ampliamente establecida y es una amenaza para los pastizales y de la parte superior de las Grandes Planicies. Se desarrollo un modelo determinístico bioeconómico incorporando las relaciones entre el apacentamiento de ovinos y el control de "Leafy spruge", la recuperación de zacates, el consumo de forraje por bovinos y los costos y retornos esperados de la empresa de ovinos. El modelo se desarrollo para evaluar la viabilidad económica de utilizar ovinos para controlar "Leafy spruge". Se desarrollaron varios escenarios visualizando escenarios posibles que enfrentan los ranchos de ganado bovino y agregando una empresa ovina para el control de "Leafy spruge". Dos niveles de rentabilidad del rebaño, uno basado en el nivel de eficiencia alcanzado por ranchos borregueros establecidos y uno substancialmente menor que la eficiencia típicamente lograda por la industria de ovinos, se combinaron con deuda y no deuda para representar el mejor y peor de los escenarios respectivamente. En todos los escenarios examinados, en las situaciones que representaron el mejor de los casos, el utilizar ovinos para controlar "Leafy spruge" fue económicamente viable. En las situaciones del peor de los casos la economía de utilizar ovinos para el control de "Leafy spruge"se mezclo a través de los escenarios examinados. El control de "Leafy spruge" con una pobre eficiencia del rebaño, altos gastos de cercos y un pastizal improductivo generalmente no fue económico. Situaciones con bajos costos de cercado, pastizales moderadamente productivos y baja eficiencia del rebaño resultaron en menos perdidas económicas que el no tratamiento. Los retornos actuales del control de "Leafy spruge"en la mayoría de los ranchos probablemente caería entre los extremos examinados.

established infestations on untillable land (Lym 1997). As a result, leafy spurge control must be approached as a long-term management problem since (1) the weed cannot be eradicated economically with current technology, ${ }^{1}$ (2) uncontrolled infestations have detrimental long-term consequences for grazing land, and (3) time lags often exist between treatments and returns. Although several control methods are available to land managers, each control approach has limitations in its applicability and effectiveness in treating leafy spurge infestations. Grazing with sheep and goats, while known to be effective in controlling leafy spurge since the 1930s (Helgeson and Thompson 1939, Helgeson

${ }^{1}$ Leafy spurge has been eradicated using tillage activities in combination with fertilization in cropland (Lym and Messersmith 1993). These techniques are not readily feasible in most grazing land situations. 
and Longwell 1942), has lacked widespread adoption (Sedivec et al. 1995, Sell et al. 1999a). The apparent inability of biological agents to establish on many leafy spurge infestation sites (Bangsund et al. 1999), the economic and environmental restrictions and constraints associated with herbicides, and the ineffectiveness of cultural controls (e.g., mowing, burning) have led to a renewed interest by land owners in evaluating sheep grazing as a leafy spurge control method.

Sheep will graze leafy spurge, and if used properly, reduce infestation density and prevent infestation spread over time (Helgeson and Longwell 1942, Johnston and Peake 1960, Bowes and Thomas 1978, Lacey et al. 1985, Sedivec et al. 1995). Since sheep will not eradicate leafy spurge and controlling leafy spurge with sheep requires grazing over several years, using sheep as a leafy spurge control must be considered a long-term management strategy. Preliminary research on the economic feasibility of using sheep to control leafy spurge has not evaluated the longterm benefits or costs of grazing control strategies (Sedivec et al. 1995, Williams et al. 1996). Since leafy spurge control must be approached as a long-term management problem, information on the economic feasibility of leafy spurge control methods must also be based on long-term treatment benefits and costs (Bangsund et al. 1996).

A goal of this study was to provide economic information for assessing long-term grazing control strategies for leafy spurge. Sell et al. (1999b) identified economic information on leafy spurge controls as one of the most desired types of weed control information sought by ranchers, local decision makers, and public land managers in the Upper Great Plains.

\section{Methods}

A deterministic, simulation model was developed to evaluate the economics of using sheep to control leafy spurge and determine which variables influence the economic feasibility of various grazing strategies (Fig. 1). The economic feasibility of using sheep to control leafy spurge was evaluated using selected scenarios which reflect likely situations facing cattle ranches adding a sheep enterprise for leafy spurge control. The annual difference between treatment expenses, and the value of grazing outputs recovered and retained through treatment were discounted over 10 years to provide a long-term perspective for various control scenarios. General

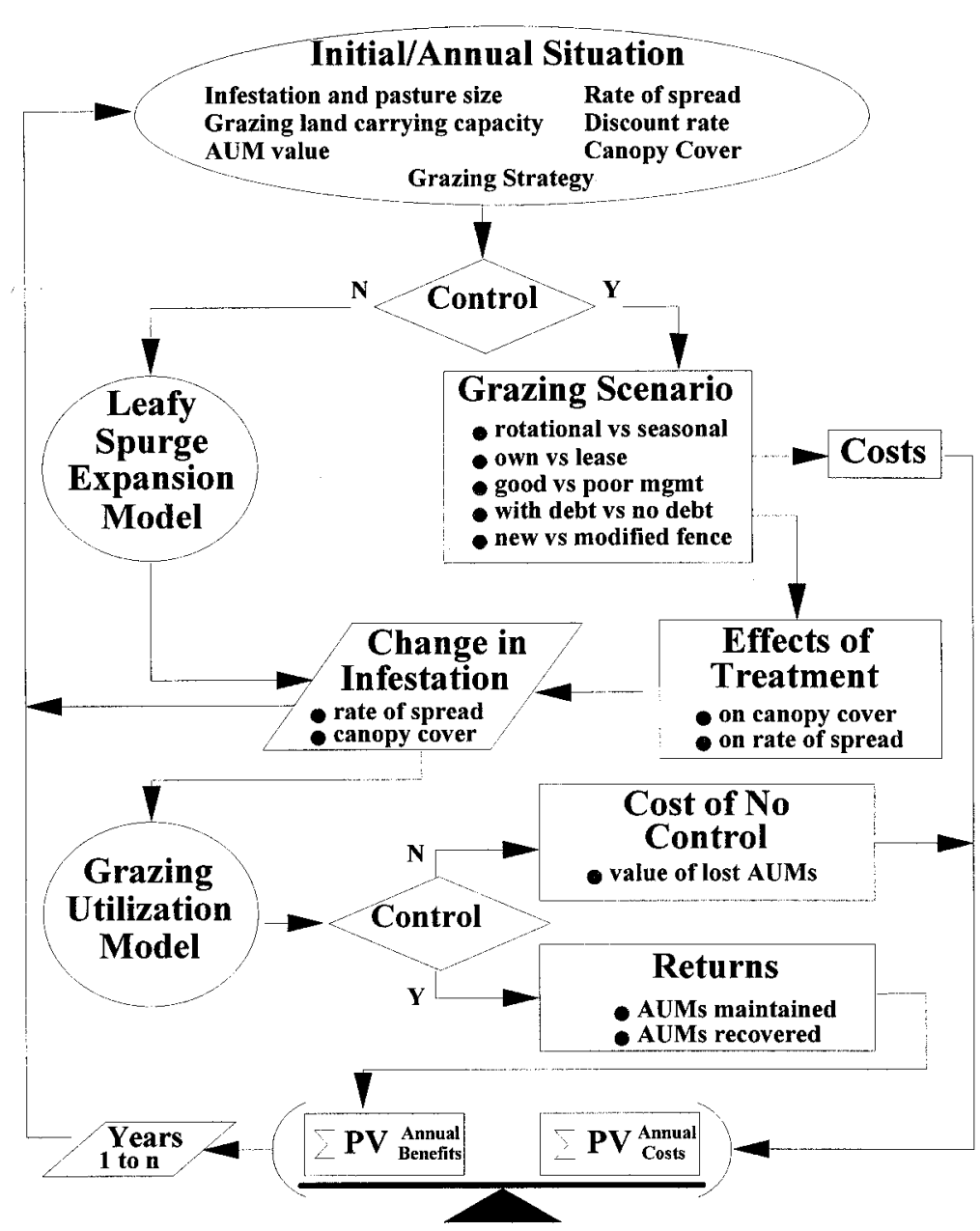

Fig. 1. Economic evaluation model of the control of leafy spurge using sheep grazing.

model design was adapted from Bangsund et al. (1996).

\section{Model Development}

Documented effects of long-term sheep grazing on infestation canopy cover, rate of spread, grass rejuvenation (i.e., increase in grass production within the infestation resulting from grazing controls), and cattle grazing recovery rates (i.e., amount of available grass cattle will consume upon reduction in leafy spurge canopy cover) were not available. The relationships used in this study were developed from a combination of short-term data from unpublished grazing trials and input from range and weed scientists. Sufficient data from grazing trials were not available to develop control relationships over a 10-year period. To conduct a long-term economic evaluation of sheep grazing, it was necessary to largely rely on the assumptions and "best estimates" of range and weed scientists. Until these relationships are refined through additional grazing trials, much of the economic analysis provided by this research remains sensitive to those key assumptions and relationships.

The model included the relationship between leafy spurge control using sheep and forage recovery by cattle, sheep enterprise budgets, leafy spurge growth (patch expansion) component, and an economic analysis component. Leafy spurge expansion was based on a model adapted from Bangsund et al. (1993). Expected control was modeled as a function of time (i.e., years grazed), assuming the same flock is used to graze leafy spurge annually, proper stocking rates are maintained, and grazing controls are properly implemented (Fig. 2) (personal communication, Lym, Kirby, Sedivec 1999). Control was defined as a percentage of the previous year's canopy cover (e.g., canopy cover(year 2)[canopy cover(year 2) x control(year 2)] = canopy cover(year 3)\}.

The rate of infestation spread under sheep grazing was modeled as a function of the number of years of control. Since the model can accommodate various rates of expansion, reduction in the rate of 

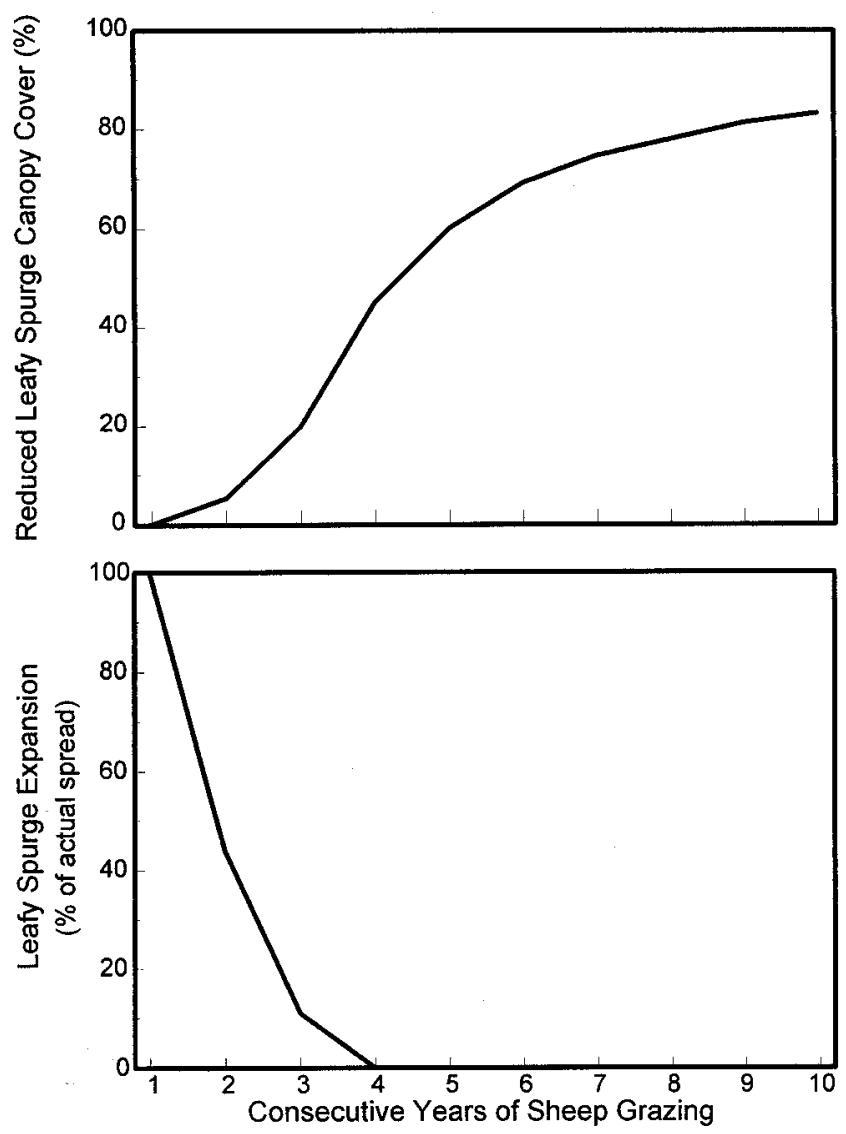

Fig. 2. Projected rate of leafy spurge expansion and leafy spurge canopy cover reduction with seasonal sheep grazing (personal communication, Lym, Kirby, and Sedivec 1999).

spread was estimated as a percentage of actual spread (Fig. 2). Infestation spread in the analysis was $0.6 \mathrm{~m}_{\text {year }}{ }^{-1}$.

The relationship between lost cattle grazing capacity and infestation canopy cover was estimated from consultation with range scientists and was based on a linear function of canopy cover (Fig. 3). Grazing losses for cattle in leafy spurgeinfested pastures stem from avoiding forage within infestations and from decreased herbage production within dense infestations (Lym and Messersmith 1985, Lym and Kirby 1987, Kronberg et al. 1993). Once a leafy spurge infestation represents about one-third of the canopy cover (top growth) within the patch, cattle grazing within the infestation has been eliminated. The model assumes that a $30 \%$ canopy cover would roughly translate to about 80 to 130 stems $\mathrm{m}^{-2}$.

The approach for estimating the amount of forage consumed by cattle as a result of leafy spurge treatment was based on the amount of forage available within leafy spurge infestations (as a percentage of uninfested carrying capacity) and the amount of available carrying capacity that cattle would utilize. The model assumes that as leafy spurge infestations increase in canopy cover, grass production within those infestations decreases (Fig. 4). The relationship between leafy spurge canopy tion, Lym, Kirby, and Sedivec 1999). cover and grass production was based on the ability of leafy spurge to out compete native vegetation and create near monocultures (Watson 1985, Messersmith et al. 1985).

Because leafy spurge control was based on the number of consecutive years of sheep grazing, the rate of forage consumed by cattle within the infestation was also modeled as a function of the number of years of sheep grazing (Fig. 5). Since sheep will not eradicate leafy spurge, forage consumption (as a percent of carrying capacity) by cattle within leafy spurge infestations was assumed to remain below that of uninfested rangeland. Some minor avoidance to grazing within the infestation may exist and grass production within the infestation would likely remain below that of uninfested rangeland, due to competition by leafy spurge roots. Grass production within the infestation was modeled to increase over time as infestation canopy cover was reduced; however, constraints on the increase in grass production were incorporated to prevent forage production from equaling the productivity of uninfested rangeland. The model assumes that cattle are properly stocked for the carrying capacity of the pasture.

\section{Sheep Enterprises}

Several possible sheep enterprise scenarios were modeled after typical operations in western North Dakota (Nudell et al. 1998). Breeding stock was commercial Western White-faced ewes and blackfaced rams. Ewes were assumed to lamb

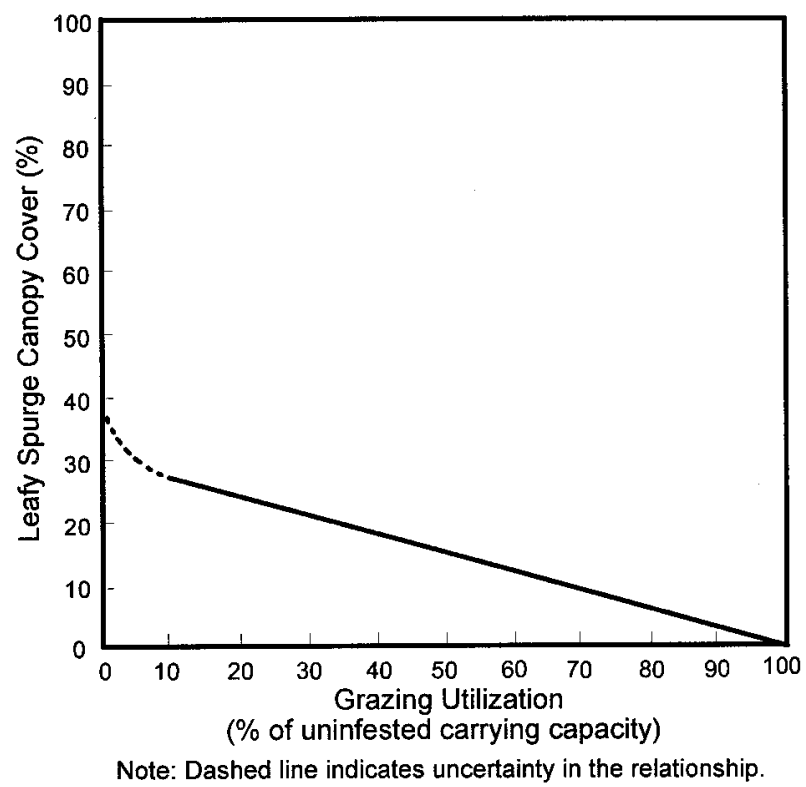

Fig. 3. Assumed reduction in cattle grazing within leafy spurge infestations (personal communica- 


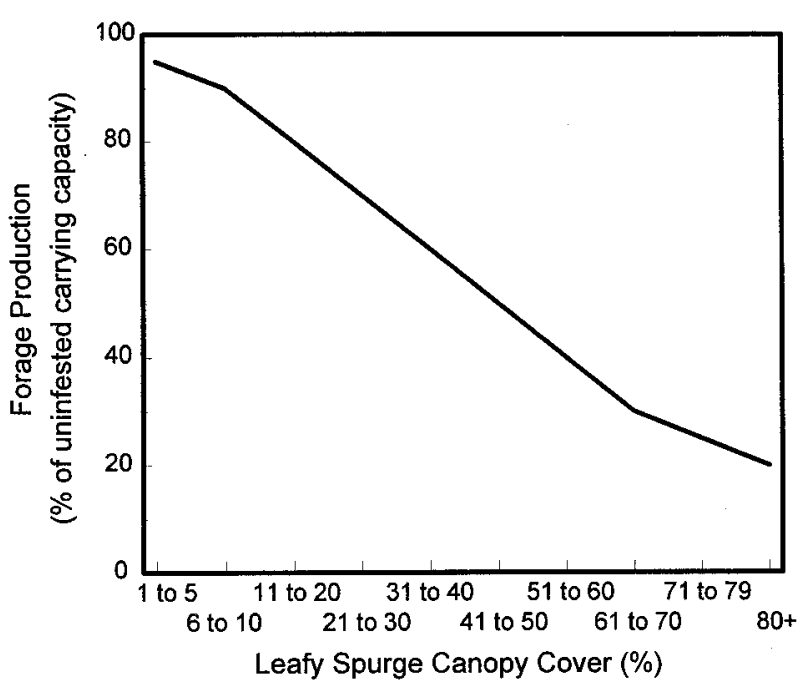

Fig. 4. Postulated relationship between grass production and leafy spurge infestation canopy cover (personal communication, Lym, Kirby, and Sedivec 1999). in February, with spring lambs fed during the summer and marketed in the fall as slaughter lambs. Replacements were raised. Only ewes and rams were used for leafy spurge control. Sheep budgets were prepared using an enterprise analysis program for sheep producers (Hughes et al. 1997).

Variations in the sheep enterprises were limited to flock proficiency (e.g., lambing rate, weaning weight, death loss), size, and debt. Because flock proficiency will likely vary depending upon the management ability, experience, animal husbandry, and willingness and ability of ranchers and producers to devote resources to flock management, 2 levels of flock proficiency were considered. The addition of a sheep enterprise for leafy spurge control was assumed to not affect the management of the existing cattle enterprise. One scenario was based on flock proficiency equal to that of established North Dakota sheep producers, whereas the other scenario was based on flock proficiency substantially less than typically achieved by established sheep producers (Table 1) (Nudell et al. 1998, N.D. Farm and Ranch Business Management 1999).

Sheep enterprises were further categorized by size and debt. Small flocks had 60 ewes and large flocks had 200 ewes. Half of the sheep enterprises had no debt, meaning that breeding stock, facilities, and equipment were either already available or purchased without financing. The enterprises with debt had $50 \%$ of the equipment and facility requirements financed for 5 years and $50 \%$ of breeding stock purchas-
Table 1. Sheep enterprise coefficients and characteristics.

\begin{tabular}{lcc}
\hline \hline & \multicolumn{2}{c}{ Level of Flock Proficiency } \\
\cline { 2 - 3 } Characteristic/Coefficients & Good & Poor \\
\hline Selling characteristics & 1.65 & 1.65 \\
Market lamb price $\left(\$ \mathrm{~kg}^{-1}\right)$ & 0.77 & 0.77 \\
Cull ewe price $\left(\$ \mathrm{~kg}^{-1}\right)$ & 50.0 & 50.0 \\
Cull ram price $\left(\$ \mathrm{hd}^{-1}\right)$ & 1.10 & 1.10 \\
Wool price $\left(\$ \mathrm{~kg}^{-1}\right)$ & 54.4 & 47.6 \\
Market lamb weight $\left(\mathrm{kg} \mathrm{hd}^{-1}\right)$ & 22.7 & 20.4 \\
Lamb weaning weight $\left(\mathrm{kg} \mathrm{hd}^{-1}\right)$ & 68.0 & 68.0 \\
Cull ewe weight $\left(\mathrm{kg} \mathrm{hd}^{-1}\right)$ & 4.5 & 4.5 \\
Wool production $\left(\mathrm{kg} \mathrm{ewe}^{-1} \mathrm{year}^{-1}\right)$ & & \\
Flock Proficiency & 100 & 100 \\
Conception rate $(\%)$ & 150 & 100 \\
Lambing rate $(\%)$ & 10 & 12 \\
Lamb death loss $(\%)$ & 5 & 5.5 \\
Ewe death loss $(\%)$ & 20 & 20 \\
Replacement rate $(\%)$ & 33 & 33 \\
Ewes per ram &
\end{tabular}

es financed for 3 years. Annual interest rate was $10 \%$. Thus, budgets for 8 combinations of flock proficiency, size, and debt were compiled.

The number of sheep needed for leafy spurge control generally decreases after the first 3 years and again after 7 years of a seasonal grazing control program (Sedivec et al. 1995). Stocking rate reductions for sheep were estimated as a percentage of the initial stocking rate. Budgets for each production scenario were estimated annually over a 10 -year period to accommodate changing flock size and corresponding changes in debt (Table 2). Production coefficients, selling prices, and variable expenses per ewe were not adjusted over the 10-year period.

Fencing expenses included modifying an existing fence or constructing new fence. Material costs were based on 1999 retail prices in western North Dakota. Modified fencing was based on adding 2 barb wires to an existing 3- or 4-wire fence. New fence was based on 6 barb wires, including requirements for line and corner posts. Pastures were assumed to be relatively flat and square. Five percent of total fencing expense was charged to the enterprises annually.

Several key assumptions were made in the preparation of the sheep budgets. Economic charges (depreciation) were not included for machinery and equipment that generally overlaps with cattle production (e.g., stock trailers, loader tractor, pickup). All pastures were assumed to have water present in sufficient quantities and available to sheep. Water maintenance and pasture expenses were not included. Selling prices for lambs, cull ewes, and 
Table 2. Annual net revenues to unpaid labor, management, and equity per ewe for various sheep enterprise scenarios over a 10-year period, western North Dakota.

\begin{tabular}{|c|c|c|c|c|c|c|c|c|}
\hline \multirow[b]{4}{*}{ Years } & \multicolumn{4}{|c|}{ With Debt } & \multicolumn{4}{|c|}{ No Debt } \\
\hline & \multirow{2}{*}{\multicolumn{2}{|c|}{$\begin{array}{l}\text { Small }^{1} \\
\text { Fencing }^{2}\end{array}$}} & \multirow{2}{*}{\multicolumn{2}{|c|}{$\begin{array}{c}\text { Large }^{1} \\
\text { Fencing }\end{array}$}} & \multirow{2}{*}{\multicolumn{2}{|c|}{$\begin{array}{c}\text { Small } \\
\text { Fencing }\end{array}$}} & \multirow{2}{*}{\multicolumn{2}{|c|}{$\begin{array}{c}\text { Large } \\
\text { Fencing }\end{array}$}} \\
\hline & & & & & & & & \\
\hline & New & Modify & New & Modify & New & Modify & New & Modify \\
\hline & \multicolumn{8}{|c|}{ - - - - - - - - - - - - - - - - - - - - - - - - - - - - (\$) - - - - - - - - - - - - - - - - - - - - - - - - - - - } \\
\hline & \multicolumn{8}{|c|}{ 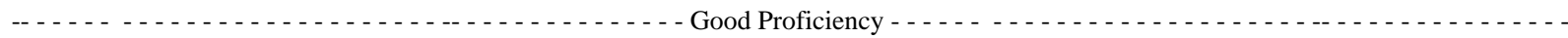 } \\
\hline $1 \& 2$ & 23.55 & 28.85 & 39.94 & 41.00 & 30.57 & 33.80 & 44.41 & 45.06 \\
\hline 3 & 15.48 & 20.78 & 31.57 & 32.63 & 22.49 & 25.72 & 36.05 & 36.70 \\
\hline $4 \& 5$ & 19.36 & 28.19 & 30.28 & 32.05 & 24.94 & 30.33 & 31.66 & 32.74 \\
\hline 6 & 24.94 & 30.33 & 31.66 & 32.74 & 24.94 & 30.33 & 31.66 & 32.74 \\
\hline 7 & 19.53 & 24.92 & 26.66 & 27.74 & 19.53 & 24.92 & 26.66 & 27.74 \\
\hline \multirow[t]{2}{*}{$8-10$} & 14.56 & 22.65 & 29.67 & 31.29 & 14.56 & 22.65 & 29.67 & 31.29 \\
\hline & \multicolumn{8}{|c|}{ 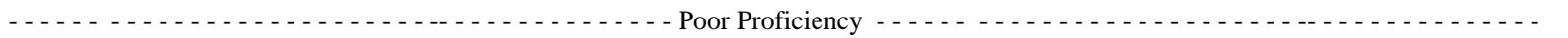 } \\
\hline $1 \& 2$ & -12.12 & -6.82 & -4.56 & -3.50 & -5.22 & -1.99 & -0.18 & 0.47 \\
\hline 3 & -22.99 & -17.69 & -15.71 & -14.65 & -16.08 & -12.85 & -11.34 & -10.69 \\
\hline $4 \& 5$ & -14.69 & -5.86 & -2.96 & -1.19 & -9.11 & -3.72 & -1.58 & -0.50 \\
\hline 6 & -9.11 & -3.72 & -1.58 & -0.50 & -9.11 & -3.72 & -1.58 & -0.50 \\
\hline 7 & -17.22 & -11.83 & -9.37 & -8.29 & -17.22 & -11.83 & -9.37 & -8.29 \\
\hline $8-10$ & -16.88 & -8.79 & -3.64 & -2.02 & -16.88 & -8.79 & -3.64 & -2.02 \\
\hline
\end{tabular}

${ }_{1}^{1}$ Small flocks based on 60 ewes and large flocks based on 200 ewes. Flock reductions occurred in years 4 and 8.

2 New fencing expenses based on constructing a 6-wire fence, with requirements for line and corner posts. Modified fence included adding 2 barb wires to an existing $3-$ or 4 -wire fence. New fence cost was estimated at $\$ 831 \mathrm{~km}^{-1}$. Modified fence cost was estimated at $\$ 159 \mathrm{~km}^{-1}$.

wool represented a 5-year average of N.D. prices (N.D. Agricultural Statistics Service, various issues). Net returns to unpaid labor, equity, and management for the various sheep enterprises with debt ranged from $(\$ 12.12)$ to $\$ 41.00$ ewe $^{-1}$ in year 1 of the 10-year budgeting period (Table 2). Net returns for debt-free sheep enterprises ranged in year 1 of the 10-year budgeting period from $(\$ 5.22)$ to $\$ 45.06$ ewe $^{-1}$ (Table 2).

\section{Treatment Scenarios}

The model was structured to assess control scenarios by (1) comparing only control costs with control benefits (i.e., classic economic cost/benefit approach) and (2) determining potential overall losses with control (using sheep) vs losses without control (i.e., least-loss or costeffective approach). Grazing scenarios where cumulative discounted annual benefits are greater than cumulative discounted annual costs are economically feasible ${ }^{2}$. In the second approach, grazing scenarios that are not economical (i.e., discounted costs greater than discounted benefits) may still result in less economic loss than incurred without control. Under those conditions, using grazing controls would be economically advisable, provided more economical control options were not avail-

\footnotetext{
${ }^{2}$ The concept of financial feasibility (i.e., constraints on or availability of resources and cash flow needed for flock, equipment, building, and fencing purchases) was not examined. Other constraints, such as availability of labor, were not addressed.
}

able. In the event that an existing grazing strategy results in more loss than without control, a "do nothing" strategy or one employing other methods (i.e., herbicides, biological agents, combined controls) might be optimal.

A mixed-species, seasonal grazing approach was modeled based on sheep grazing leafy spurge infested pastures for 4 consecutive months. One ewe can be added per cow without reducing cattle production (Umberger et al. 1984, Glimp 1988, Nelson et al. 1992, Sedivec et al. 1995). Adding sheep at a rate of 2.5 ewes $\mathrm{ha}^{-1}$ of leafy spurge was assumed to not violate the rule of allowing one ewe per cow to a given pasture. The stocking rate for cattle was assumed to increase over time because of improved levels of leafy spurge control. The change in forage production for cattle was measured in AUMs and assumed (1) ranchers adjusted cattle stocking rates or grazing duration to accommodate the increase in grazing output, (2) initial cattle stocking rates were appropriate for the land before leafy spurge treatment, and (3) sheep stocking rates were reduced over time.

Although a number of scenarios were used to evaluate the economics of using sheep to control leafy spurge over a wide range of possibilities, several variables were held constant across all analyses. Pasture size was limited to 141.6 ha. Uncontrolled infestation spread was limited to 0.6 radial $\mathrm{m}_{\text {year }}{ }^{-1}$ and infestations were assumed to increase in canopy cover by $1.5 \%$ annually without treatment. Grazing outputs were valued at $\$ 15 \mathrm{AUM}^{-1}$
(N.D. Agricultural Statistics Service, various issues). Leafy spurge infestation canopy cover was limited to 5,15 , and $30 \%$, which represented low (17\% loss), moderate (50\% loss), and high $(100 \%)$ grazing losses within the infestation, respectively. Treatment benefits and costs were discounted annually at $4 \%$.

\section{Results}

Results from the model provided a quantitative look at the long-term economic feasibility of adding a sheep enterprise to control leafy spurge under a variety of plausible situations facing landowners in the Upper Great Plains. The model also was used to assess the influence of the magnitudes of various economic and physical variables on returns from treatment.

\section{Benefit-Cost Analysis}

For control scenarios including good flock proficiency, positive net returns from leafy spurge control were substantial. Total net returns (discounted treatment returns less discounted treatment costs) from leafy spurge control using sheep, with rangeland carrying capacities of 0.5 AUMs ha ${ }^{-1}$, ranged from \$303 to \$541 ha of leafy spurge over a 10 -year period, depending upon fencing obligations, debt, and flock size. With rangeland carrying capacities of 1.9 AUMs ha ${ }^{-1}$, total discounted net returns from leafy spurge control ranged from $\$ 339$ to $\$ 647 \mathrm{ha}^{-1}$ of leafy spurge over a 10-year period (Table 3 ). 
Table 3. Total discounted net returns per hectare over a 10-year period, control of leafy spurge using sheep under seasonal grazing.

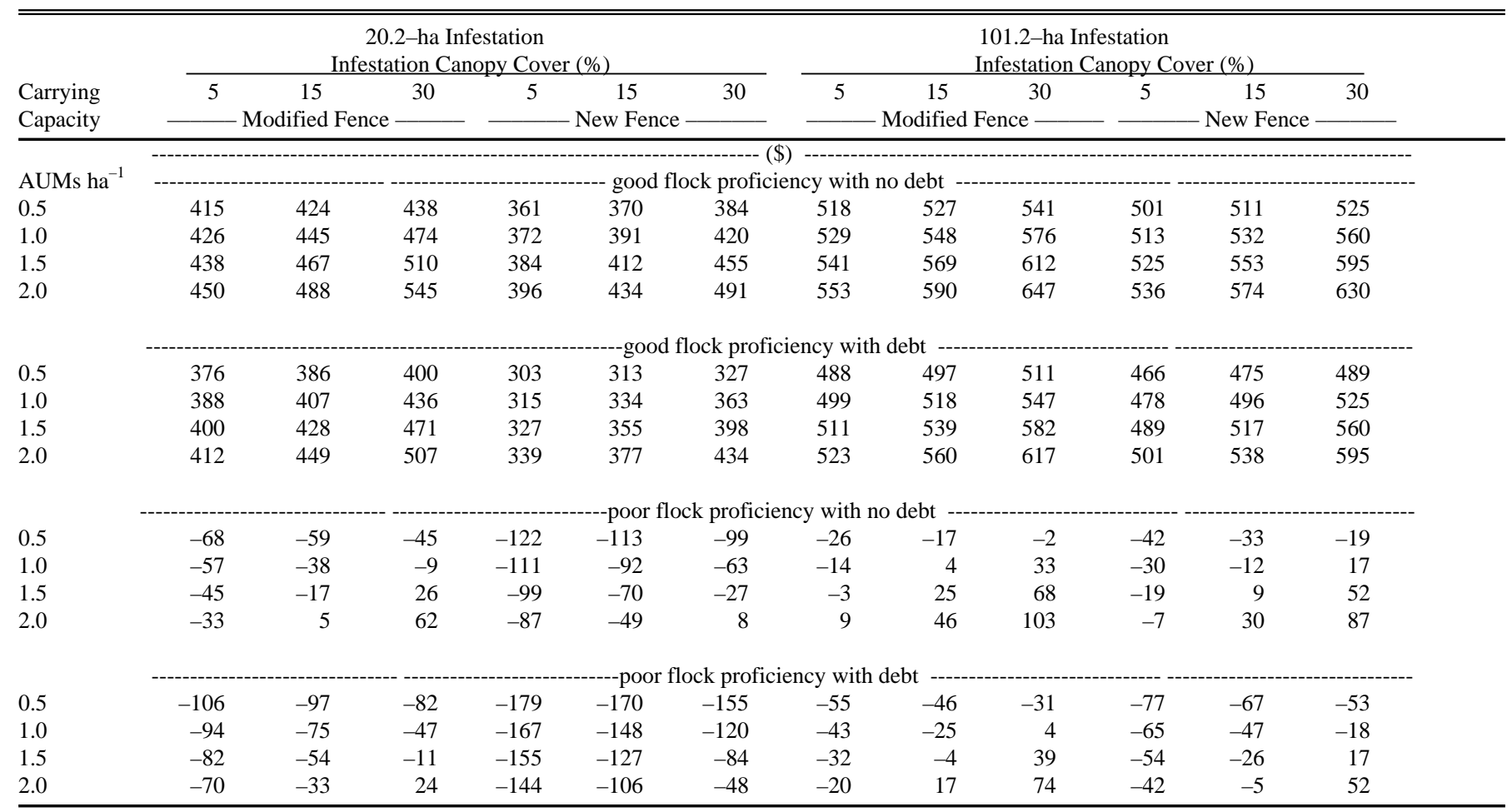

For control scenarios including poor flock proficiency, net returns from leafy spurge control were sensitive to rangeland productivity and leafy spurge canopy cover. Total net returns from leafy spurge control, with rangeland carrying capacities of 0.5 AUMs ha ${ }^{-1}$, ranged from $\$(179)$ to $\$(2) \mathrm{ha}^{-1}$ of leafy spurge over the 10 -year period, depending upon fencing obligations, debt, and flock size. With rangeland carrying capacities of 1.9 AUMs ha ${ }^{-1}$, total net returns from leafy spurge control ranged from $\$(144)$ to $\$ 103 \mathrm{ha}^{-1}$ of leafy spurge (Table 3).

Generally, discounted net returns from leafy spurge control were about $\$ 30$ to $\$ 57$ $\mathrm{ha}^{-1}$ higher for scenarios having no debt vs those with debt (Table 3). Over a 10-year period, net returns from leafy spurge control were $\$ 64 \mathrm{ha}^{-1}$ less for scenarios with new fence vs modified fence scenarios with small infestations and were $\$ 19 \mathrm{ha}^{-1}$ less with large infestations. Discounted net returns $\mathrm{ha}^{-1}$ from leafy spurge control were higher with large infestations (101.2 ha) vs small infestations (20.2 ha) across all scenarios. In a 10-year period, discounted net returns from large infestations compared with small infestations increased by $\$ 42$ to $\$ 111$ ha $^{-1}$ for all scenarios with modified fence. For all scenarios with new fence over the same period, net returns from leafy spurge control improved by $\$ 82$ to
$\$ 163 \mathrm{ha}^{-1}$ when comparing small with large infestations.

\section{Least-loss Analysis}

Least-loss analysis compares economic losses incurred if a leafy spurge infestation was uncontrolled to losses incurred with control. Where economic losses with treatment are more than the economic losses incurred without control, the treatment program or strategy would not be recommended.

The good flock proficiency scenarios had positive enterprise returns, which resulted in positive discounted net returns from control. Thus, least-loss analyses were not conducted for those scenarios. Least-loss analyses were conducted for the poor flock proficiency scenarios.

Over a 10-year period, most sheep grazing scenarios with high rangeland productivity and high leafy spurge canopy cover resulted in less economic loss than with no control (Table 4). Many of the grazing scenarios with new fence and low leafy spurge canopy cover would not be recommended, although most scenarios with new fence and high leafy spurge canopy cover could be recommended for all but the least productive rangeland. In a 10year period, none of the small flock scenarios would be recommended at rangeland carrying capacities of 0.494 AUMs $\mathrm{ha}^{-1}$ or less (Table 4).

\section{Factors Influencing Returns from Control}

Many factors may influence the economics of using sheep to control leafy spurge. One of the biggest factors influencing returns from leafy spurge control, when a sheep enterprise is added to an existing ranch, would be enterprise returns. When enterprise returns were positive, discounted net returns from leafy spurge control were positive in all of the treatment scenarios examined. In some cases, economic returns from leafy spurge control were substantial. When sheep enterprise returns were negative (because of assumed poor flock proficiency, Table 2 ), other factors determined the economics of control.

Large infestations were more economical to treat than small infestations, based on the fundamental assumptions used in this study. Fencing costs per hectare were modeled to be less with larger infestations, since overall pasture size was fixed across infestation sizes. In reality, per ha fencing costs for a 101.2-ha infestation could be the same as for a 20.2-ha infestation. Because some efficiencies in sheep production occur when moving from small flocks (e.g., 50 ewes) to larger flocks (e.g., 200 ewes), enterprise returns improved with flock size. Thus, lower per ewe fencing costs and more favorable enterprise 
Table 4. Least-loss analysis ${ }^{1}$ of the control of leafy spurge using sheep under seasonal grazing.

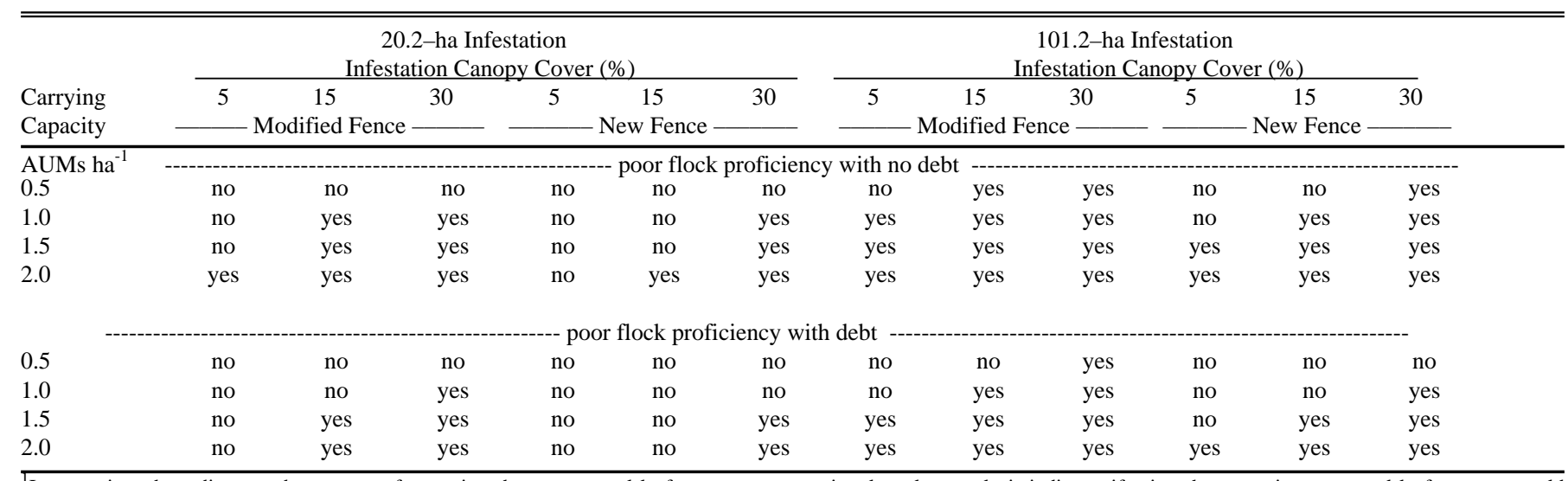

In scenarios where discounted net returns from using sheep to control leafy spurge are negative, least-loss analysis indicates if using sheep grazing to control leafy spurge would result in less economic loss than if the leafy spurge infestation was left uncontrolled. A "yes" implies that the scenario will result in less economic loss than no treatment. A "no" implies that the scenario will result in more economic loss than no treatment.

returns were major reasons that returns from control were more favorable with larger infestations.

Returns from control improved as leafy spurge canopy cover and the resulting forage suppression increased. As grazing losses for cattle increase, potential returns from leafy spurge control also increase. This relationship directly influenced the amount of grazing recovery that could be expected from leafy spurge control. Returns from leafy spurge control improved proportionally to changes in grazing recovery. Since sheep grazing was only evaluated using relatively large infestations, the value of grazing retention (i.e., grazing output retained by preventing infestation spread) was a minor component of overall returns from treatment. Higher infestation densities and levels of canopy cover would affect net returns from leafy spurge control if grass recovery and forage available within the infestations differed from the levels/relationships used in this study.

Returns from control were directly proportional to rangeland productivity. Thus, holding all other factors constant, returns were greater on more productive rangeland. Similarly, holding all factors constant, returns change as AUM values change.

Enterprise debt affected discounted net returns from leafy spurge control. The level of debt used in this study had sufficient influence on returns from control (about $\$ 30$ to $\$ 57 \mathrm{ha}^{-1}$ over a 10 -year period) to affect decisions regarding the economics of using sheep to control leafy spurge. The effects of added debt were most influential in the poor flock proficiency scenarios. When enterprise returns were negative, increased expense from additional enterprise debt was sufficient in some scenarios that sheep grazing of leafy spurge would be uneconomical.

The added expense for new fence had a much greater effect on discounted net returns for controlling small infestations (expense was divided among fewer ha). For example, with small infestations, discounted net returns from control improved about $\$ 64 \mathrm{ha}^{-1}$ when compared to scenarios with modified fence. Similarly, with large infestations, returns from control improved by only $\$ 19 \mathrm{ha}^{-1}$ when compared to scenarios with modified fence.

\section{Alternative Scenarios}

Additional treatment scenarios were examined, although not presented for sake of brevity. Twice-over rotational grazing systems were somewhat less economical than seasonal grazing strategies, due to reduced leafy spurge control and higher fencing costs (i.e., added cost for internal fences). However, over a 10-year period, the difference between discounted net returns from rotational and seasonal grazing strategies did not substantially influence the economics of using sheep to control leafy spurge.

Leasing sheep for leafy spurge control may be an alternative to adding a sheep enterprise to an existing ranch. Lease rates above $\$ 1$ head $^{-1}$ month $^{-1}$ did not provide positive net returns in many of the control scenarios examined. Lease rates of $\$ 1$ head $^{-1}$ month $^{-1}$ would likely result in positive net returns from control in many treatment scenarios and provide less economic loss than no treatment across a range of treatment scenarios.

Different time periods were also examined. Discounted net returns from treatment were not as favorable in a 5-year period, largely because sheep grazing requires several years to reduce infestation densities. Discounted net returns improved when treatment scenarios were increased from 10- to 15-year periods. Returns in the various periods would be sensitive to changes in the discount rate.

\section{Conclusions}

The basic premise for this study was that sheep would be used to control leafy spurge in rangeland by adding a sheep enterprise to an existing ranch. Sheep grazing as a leafy spurge control method was economical across many enterprise scenarios. In many of the scenarios with negative sheep enterprise returns, the benefits of leafy spurge control outweighed the negative enterprise returns.

In addition to economic criteria, other factors, such as labor and financial constraints, need to be considered before implementing a grazing control strategy. Even though returns may be positive for many control scenarios, they may not be sufficient to adequately compensate for unpaid inputs. If these constraints do not prohibit adding a sheep enterprise to an existing ranch, the economics of using sheep grazing to control leafy spurge appear favorable.

The economics of using sheep to control leafy spurge were sensitive to the grazing recovery rates assumed in this study. Long-term research over a wide range of treatment conditions is needed to refine the control responses assumed in this study. Additional refinement in those relationships would add confidence to the study results.

Several factors can influence costs and returns from using sheep grazing to control leafy spurge. As a result, a careful 
evaluation using site- and rancher-specific inputs would be recommended before implementing sheep grazing as a leafy spurge control method.

\section{Literature Cited}

Bangsund, D.A., F.L. Leistritz, and J.A. Leitch. 1999. Assessing economic impacts of biological control of weeds: The case of leafy spurge in the northern Great Plains of the United States. J. Environ. Manage. $56: 35-43$.

Bangsund, D.A., J.A. Leitch, and F.L. Leistritz. 1996. Economics of herbicide control of leafy spurge (Euphorbia esula L.). J. Agr. and Resource Econ. 21(2):381-395.

Bangsund, D.A., R.K. Stroh, and J.A. Leitch. 1993. Leafy spurge patch expansion. Natur. Areas J. 13(2):131-132.

Bowes, G.G. and A.G. Thomas. 1978. Longevity of leafy spurge seeds in the soil following various control programs. J. Range Manage. 31:137-140.

Glimp, H.A. 1988. Multi-species grazing and marketing. Rangelands. 10:275-278.

Hanson, H.C. and V.E. Rudd. 1933. Leafy spurge life history and habits. Agr. Exp. Sta. Bull. 226. N.D. Agr. Coll., Fargo, N.D.

Helgeson, E.A. and E.J. Longwell. 1942. Control of leafy spurge by sheep. N.D. Agr. Exp. Sta. Bimonthly Bull. 4(5):10-12.

Helgeson, E.A. and E.J. Thompson. 1939. Control of leafy spurge by sheep. N.D. Agr. Exp. Sta. Bimonthly Bull. 2(1):5-9.

Hughes, H., D. Nudell, and R. Egeberg. 1997. SheepBud Ver. 1.01. N.D. State Univ., Fargo, N.D.

Johnston, A. and R.W. Peake. 1960. Effect of selective grazing by sheep on the control of leafy spurge (Euphorbia esula L.). J. Range Manage. 13:192-195.
Kronberg, S.L., R.B. Muntifering, E.L. Ayers, and C.B. Marlow. 1993. Cattle avoidance of leafy spurge: A case of conditioned aversion. J. Range Manage. 46(4):364-366.

Lacey, C.A., P.K. Fay, R.G. Lym, C.G. Messersmith, B.Maxwell, and H.P. Alley. 1985. The distribution, biology, and control of leafy spurge. Cooperative Ext. Circ. 309. Mont. State Univ., Bozeman, Mont.

Lajeunesse, S., R. Sheley, R. Lym, D. Cooksey, C. Duncan, J. Lacey, N. Rees, and M. Ferrell. 1995. Leafy spurge: biology, ecology, and management. Bull. No. W1088. Mont. State Univ., Bozeman, Mont.

Leitch, J.A., F.L. Leistritz, and D.A. Bangsund. 1996. Economic effect of leafy spurge in the upper Great Plains: Methods, models, and results. Impact Assessment 14(4):419-433.

Lym, R.G. 1997. The history of leafy spurge control in North Dakota. N.D. Agr. Res.: N.D. State Univ., Fargo, N.D.

Lym, R.G. and D.R. Kirby. 1987. Cattle foraging behavior in leafy spurge (Euphorbia esula)-infested rangeland. Weed Tech. 1:314-318.

Lym, R.G. and C.G. Messersmith. 1993. Fall cultivation and fertilization to reduce winterhardiness of leafy spurge (Euphorbia esula). Weed Sci. 41:441-446.

Lym, R.G. and C.G. Messersmith. 1985. Leafy spurge control and improved forage production with herbicides. J. Range Manage. 38:386-391.

Messersmith, C.G., R.G. Lym, and D.S. Galitz. 1985. Biology of leafy spurge. p. 4256. In: A.K. Watson (ed.), Leafy spurge. Weed Sci. Soc. of Amer., Champaign, Ill.

Nelson, J., D. Landblom, S. Silky, and T. Conlon. 1992. Multi species grazing of native range in western North Dakota. p. 42-46. In: T.C. Faller (ed.), Proceedings of western Dakota sheep day. Hettinger Res. Ext. Center, Hettinger and N.D. State Univ., Fargo, N.D.
N.D. Agricultural Statistics Service. 19951999. North Dakota agricultural statistics. N.D. Agr. Stat. Serv., N.D. State Univ., and USDA, Fargo, N.D.

N.D. Farm and Ranch Business Management. 1999. 1998 annual report. N.D. Farm and Ranch Business Manage., Bismarck, N.D.

Nudell, D., H. Hughes and T. Faller. 1998. Critical control points for profitability in sheep production. N.D. Agr. Res., N.D. State Univ., Fargo, N.D.

Sedivec, K., T. Hanson and C. Heiser. 1995. Controlling leafy spurge using goats and sheep. Ext. Pub. R-1093. N.D. State Univ., Fargo, N.D.

Sell, R.S., D.A. Bangsund, and F.L. Leistritz. 1999a. Euphorbia esula: Perceptions by ranchers and land managers. Weed Sci. 47:740-749.

Sell, R.S., D.A. Bangsund, and F.L. Leistritz. 1999b. Perceptions of leafy spurge by ranch operators and local decision makers: An update. Agr. Econ. Rep. No. 316. N.D. State Univ., Fargo, N.D.

Umberger, S.H., B.R. McKinnon, and A.L. Eller. 1983. Adding sheep to cattle for increased profits. Virg. Cooperative Ext. Service Pub. 410-851. Virg. Cooperative Ext. Service, Blacksburg, Virg.

USDA. 1995. Purge spurge: Leafy spurge database. CD-ROM Ver 3.0. USDA-ARS and Mont. State Univ., Bozeman, Mont.

Watson, A.K. 1985. Integrated management of leafy spurge. p. 93-105. In: A.K. Watson (ed.), Leafy spurge. Weed Sci. Soc. of Amer., Champaign, Ill.

Williams, K.E., J.R. Lacey, and B.E. Olson. 1996. Economic feasibility of grazing sheep on leafy spurge-infested rangeland in Montana. J. Range Manage. 49(4):372-374. 